\title{
MANAJEMEN PEMBELAJARAN EKSTRAKURIKULER BERNUANSA MULTIKULTURAL DI SMA NEGERI SE-SULAWESI UTARA
}

\author{
${ }^{1}$ Sulfa Potiua*, ${ }^{2}$ Sarson W. Dj. Pomalato \\ ${ }^{1,2}$ Universitas Negeri Gorontalo \\ ${ }^{* 1}$ sulfapotiua10@gmail.com, ${ }^{2}$ sarson@ung.ac.id
}

\begin{abstract}
ABSTRAK
Penelitian ini bertujuan untuk mendeskripsikan bentuk pembelajaran ekstrakurikuler bernuansa multikultural di SMA Negeri se-Sulawesi Utara dan mendeskripsikan manajemen pembelajaran bernuansa multikultural pada kegiatan ekstrakurikuler di SMA Negeri Se-Sulawesi Utara. Adapun hasil dari penelitian ini yaitu pembelajaran ekstrakurikuler bernuansa multikultural pada SMA Negeri di Sulawesi Utara telah dilaksanakan semaksimal mungkin oleh seluruh SMA Negeri yang ada se-Sulawesi Utara. Artinya, kegiatan ektrakurikuler tersebut telah diprogramkan oleh seluruh sekolah SMA negeri yang ada di Sulawesi Utara meskipun kegiatan tersebut dilaksanakan di luar jam pelajaran. Adapun bentuk-bentuk kegiatan umum dalam kegitan ektrakurikuler di SMA Negeri se-Sulawesi Utara yaitu latihan pidato, kegiatan pramuka, dan kegiatan keagamaan yang dibina langsung oleh guru agama masing-masing. Sedangkan, pengelolaan pembelajaran bernuansa multikultural pada kegiatan ekstrakurikuler pada SMA Negeri di Sulawesi Utara yaitu melakukan perencanaan terkait kebutuhan dan kegiatan yang akan dilakukan dalam kegiatan ektrakurikuler. Perencanaan yang dimaksudkan di sini yaitu para pembina harus membuat program kegiatan di akhir tahun dan akan mulai dilaksanakan pada awal tahun berikutnya. Kemudian setelah kegitan terlaksana pimpinan melakukan pengawasan sebagai bentuk pengontrolan dari pimpinan yang bertujuan untuk mengetahui sejauhmana capaian yang dicapai dalam kegiatan ektrakurikuler. Inti dari pengawasan ini ialah kepala sekolah melakukan pengawasan sekaligus penyampaian bahwa dalam kegiatan ekstrakurikuler ini diharapkan seluruh peserta kegiatan ekstrakurikuler mampu memujudkan kebersamaan dan membentuk keakraban serta persaudaraan tanpa melihat latar belakang status agama, suku ataupun ras dari masing-masing peserta didik. Selanjutnya, ialah melakukan evaluasi yang bertujuan untuk mengetahuai hasil dari keseluruhan kegiatan terutama pada laporan kegiatan dan keuangan dari kegiatan ektrakurikuler.
\end{abstract}

Kata kunci: Manajemen, Pembelajaran Ekstrakurikuler, Multikultural, SMA Negeri di Sulawesi Utara

\begin{abstract}
This study aims to describe the form of extracurricular learning with multicultural nuances in SMA Negeri in North Sulawesi and to describe learning management in multicultural nuances in extracurricular activities at SMA Negeri in North Sulawesi. The result of this research is that multicultural nuanced extracurricular learning at public high schools in North Sulawesi has been carried out to the maximum extent possible by all public high schools throughout North Sulawesi. This means that these extracurricular activities have been programmed by all public high schools in North Sulawesi even though these activities are carried out outside of class hours. The forms of general activities in extracurricular activities at public high schools throughout North Sulawesi are speech exercises, scouting activities, and religious activities which are fostered directly by their respective religious teachers. Meanwhile, the management of learning with multicultural nuances in extracurricular activities at State Senior High Schools in North Sulawesi is planning related to the needs and activities that will be carried out in extracurricular activities. The planning intended here is that the coaches must make a program of activities at the end of the year and will begin to be implemented at the beginning of the following year. Then after the activity is carried out, the leader carries out supervision as a form of control from the leadership which aims to find out the extent of the achievements achieved in extracurricular activities. The essence of this supervision is that the principal supervises as well as conveys that in this extracurricular activity it is expected that all participants in extracurricular activities are able to realize togetherness and form intimacy and brotherhood regardless of the background of religious status, ethnicity or race of each student. Next, is to carry out an evaluation
\end{abstract}




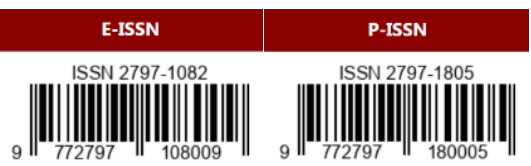

that aims to find out the results of all activities, especially on activity and financial reports from extracurricular activities.

Keywords: Management, Extracurricular Learning, Multicultural, SMA Negeri in North Sulawesi

\section{PENDAHULUAN}

Peningkatan pembelajaran bernuansa multikultural pada kegiatan ekstrakurikuler di SMA merupakan permasalahan yang perlu mendapat perhatian oleh pemerintah. Dalam proses pembelajaran bernuansa multikultural di SMA harus benar-benar di rencanakan sebagai alat pemersatu bagi seluruh peserta didik yang memiliki latar belakang yang berbeda berupa perbedaan suku, agama, ras dan adat istiadat. Salah satu cara untuk membangun persatuan dalam bingkai persaudaraan peserta didik pada tiap-tiap SMA Negeri di Sulawesi Utara yaitu dengan cara membuat kegiatan ektrakurikuler bernuansa multikultural.

Tujuan dilakukannya penanaman nilai-nilai multikultural di antaranya ialah pembentukan karakter yang cerdas dan berakhlak mulia. Sebab akhir-akhir ini tidak sedikit peserta didik ditemukan telah melakukan kekerasan terhadap sesama peserta didik di sekolah. Salah satu penyebab terjadinya kekerasan dan pertikaian antar peserta didik karena latar bekang budaya dan lingkungan yang berbeda (Barora, 2017).

Uraian di atas tampak terlihat bahwa salah satu penyebab terjadinya pertikaian pada peserta didik di sekolah ialah perbedaan budaya yang dimiliki oleh peserta didik itu sendiri. Dengan demikian, salah satu solusi pihak sekolah ialah untuk mengurangi pertikaian tersebut yaitu melakukan pengenalan budaya melalui pendidikan multikultural yang bertujuan membangun persatuan dan persaudaraan antara peserta didik yang satu dengan peserta didik lainnya.
Berdasarkan pengamatan di lapangan bahwa hampir seluruh SMA Negeri di Sulawesi Utara telah memprogramkan kegiatan ektrakurikuler di sekolah. Hal ini dilakukan agar pembelajaran bernuansa multikultural dapat terlaksana secara maksimal. Salah satu tujuan dilakukannya penelitian ini adalah untuk mengetahui lebih mendalam terkait bentuk manajemen pelaksanaan pembelajaran bernuansa multikultural pada kegiatan ektrakurikuler di SMA Negeri se-Sulawesi Utara.

Permasalahan penelitian ini dijawab dengan menggunakan konsep dasar tujuan dan tujuan kegiatan ekstrakurikuler keagamaan dan pengembangan wawasan keagamaan di sekolah. Kegiatan ekstrakurikuler sebagai wadah pendidikan peserta didik yang merupakan bagian dari kegiatan Pendidikan Agama Islam. Pendidikan Agama Islam sebagai suatu usaha sadar dalam rangka pembentukan watak dan pribadi muslim yang sesuai ajaran agama Islam. Dengan demikian, diperlukan adanya dasar atau landasan bagi terselenggaranya seluruh proses dan pelaksanaan kegiatan ektrakurikuler keagamaan dalam konteks Pendidikan Agama Islam itu sendiri.

Dengan berpedoman pada tujuan dan maksud kegiatan ekstrakurikuler di sekolah dapat ditetapkan prinsip-prinsip program ekstrakurikuler. Menurut Oteng Sutisna yang dikutip oleh B. Suryosubroto (2009) mengatakan bahwa prinsip program ektrakurikuler adalah (1) semua murid, pendidik, dan personel administrasi hendaknya ikut serta dalam usaha meningkatkan program, (2) kerja sama dalam 
tim adalah fundamental, (3) pembatasanpembatasan untuk partisipasi hendaknya dihindarkan, (4) prosesnya adalah lebih penting daripada hasil, (5) program hendaknya cukup komprehensif dan seimbang dapat memenuhi kebutuhan dan minat semua peserta didik, (6) program hendaknya memperhitungkan kebutuhan khusus sekolah, (7) program harus dinilai berdasarkan sumbangannya pada nilai-nilai pendidikan di sekolah dan efesiensi pelaksanaannya, (8) kegiatan ini hendaknya menyediakan sumbersumber motivasi yang kaya bagi kegiatan murid, dan (9) kegiatan ektrakurikuler ini hendaknya dipandang sebagai integral dari keseluruhan program pendidikan di sekolah, tidak sekedar tambahan atau sebagai kegiatan yang berdiri sendiri.

Pelaksanaan kegiatan ektrakurikuler harus dapat meningkatkan pengayaan peserta didik yang bersifat kongnitif, efektif, dan psikomotor serta mendorong penyaluran bakat dan minat peserta didik, hal ini merupakan tujuan dari pelaksanaan kegiatan ektrakurikuler yang diselenggarakan oleh sekolah.

Wawasan keagamaan, yang mengandung arti sebuah faktor yang bersifat pemikiran, potensi di mana dalam mengaktualisasikan hal tersebut sangat tergantung dengan adanya pengaruh dari lingkungan sekitarnya, demikian pula halnya dengan kegiatan ekstrakurikuler merupakan suatu kondisi yang menggambarkan tentang kegiatan tersebut dimiliki seseorang yang diaktualisasikan, baik dalam wujud ide ataupun dalam bentuk hasil karya. Hal ini hanya akan dapat terjadi jika potensi-potensi yang dimiliki seorang individu dikembangkan secara optimal dengan jalan menciptakan suatu lingkungan yang kondusif yang bersifat edukatif atau melalui proses pendidikan dan pengajaran yang dilaksanakan. Oleh sebab itu, sebagai salah satu kegiatan kurikuler, ekstrakurikuler memiliki arti penting dalam mengembangkan wawasan keagamaan dan kegiatan-kegiatan ekstrakurikuler keagamaan dalam arti peserta didik, dengan hal tersebut akan menjadikan lingkungan dan aktivitas yang bernilai pendidikan, sehingga kegiatan ekstrakurikuler keagamaan tersebut meskipun dalam pengertiannya adalah suatu kegiatan yang dilaksanakan di luar jam pelajaran, namun memiliki arti penting bagi pengembangan wawasan keagamaan para peserta didik.

Ekstrakurikuler di sekolah seakan berada dalam dua sisi mata uang. Di satu sisi keberadaannya diperlukan peserta didik sebagai media untuk mengembangkan potensi diri, selain itu diharapkan mampu mengangkat dan mengharumkan nama sekolah dengan prestasinya. Namun di sisi lain justru menjadi musabab menurunnya nilai peserta didik dan bukan tidak mungkin menjadi formalitas saja untuk mencari keuntungan (Musbikin, 2013).

Kenyataan di lapangan memang menunjukkan bahwa kegiatan ektrakurikuler mendapat proporsi yang tidak seimbang. Kurang mendapat perhatian, bahkan cenderung disepelekan. Perhatian sekolahsekolah juga masih kurang serius, hal ini terlihat dari kurangnya dukungan yang memadai baik dari segi dana, perencanaan dan pelaksanaan serta perannya sebagai bagian dari evaluasi keberhasilan peserta didik.

Padahal di kalangan peserta didik, banyak proses aktualisasi potensi peserta didik yang terjadi melalui kegiatan ekstrakurikuler. Misalnya aktualisasi tentang kepemimpinan, kesenian, olahraga, kepekaan sosial, nilai relegius, pembentukan akhlak mulia dan lain sebagainya sering muncul ketika ektrakurikuler. 


\section{METODE PENELITIAN}

Jenis penelitian yang digunakan dalam penelitian ini adalah penelitian kualitatif dengan analisis deskriptif. Penelitian kualitatif yakni mengumpulkan informasi mengenai status gejala yang ada, yaitu keadaan gejala menurut apa adanya tentang suatu variabel, gejala dan keadaan (Arikunto, 1998). Secara teoritis, penelitian deskriptif adalah penelitian yang terbatas pada usaha mengungkap suatu masalah dan keadaan sebagaimana adanya sehingga hanya merupakan penyingkapan fakta dengan menganalisis data (Arikunto, 1998). Dalam penelitian deskriptif ini penulis berusaha mencatat, menganalisis dan meninterpretasi kondisi yang ada di lapangan. Artinya, mengumpulkan informasi mengenai situasi yang ada sesuai dengan variabel yang menjadi indikator dalam penelitian ini. Dengan tehnik pengumpulan data melalui observasi, wawancara dan dokumentasi.

\section{HASIL DAN PEMBAHASAN}

\section{Bentuk Pembelajaran Ektrakurikuler}

\section{Bernuansa Multikultural di SMA Negeri} Se- Sulawesi Utara

Dalam proses belajar mengajar di beberapa SMA di Sulawesi Utara terbagi atas dua proses yaitu: proses belajar intrakurikuler dan proses belajar mengajar ekstrakurikuler. Untuk kegiatan intrakurikuler waktu dan proses pelaksanaannya disesuaikan dengan kurikulum yang sudah disusun oleh Diknas. Sedangkan, untuk pengajaran ektrakurikuler dilakukan di luar jam pelajaran sekolah atau pada jam-jam ekstra yang difasilitasi oleh masing-masing sekolah. Kegiatan pengajaran jenis ini biasanya melalui kegiatan pengajaran di luar jam sekolah seperti pramuka, kesenian, tadzkir atau ceramah keagamaan.
Kegiatan ekstrakurikuler sebagai bagian dari pada kegiatan kurikuler yang dimaksudkan adalah sebagai penunjang keberhasilan kegiatan pendidikan secara keseluruhan, tidak diatur secara formal, baik mengenai jenis ataupun bentuknya, waktu pelaksanaannya maupun ketentuan lain yang sifatnya mengikat, Oleh karena itu, di dalam pelaksaan kegiatan ekstrakurikuler yang ada di SMA se-Sulawesi Utara mencakup beberapa bentuk kegiatan, yaitu sebagai berikut.

Pertama, kegiatan seni. Kegiatan seni atau kesenian sebagai salah satu bentuk kegiatan ekstrakurikuler yang sering dilakukan oleh seluruh SMA yang ada di Sulawesi Utara dengan melibatkan beberapa orang guru sebagai pembina dalam kegiatan tersebut. Dalam kegiatan ini, para peserta didik diajarkan dengan latihan berorasi atau pidato, nyanyian solo dan vokal grup. Selain itu, ada juga kegiatan keagamaan yang masing-masing diawasi langsung oleh guru agama pada sekolah tersebut. Hal ini sebagaimana yang diutarakan oleh kepala sekolah SMA Negeri 1 Kotamobagu yang mengatakan bahwa: "Untuk mengembangkan bakat dan minat serta kreativitas peserta didik khususnya di bidang kesenian di sekolah ini, saya selaku kepala sekolah selalu berusaha dan memotivasi kepada seluruh peserta didik dan para pembina dalam kegiatan ektrakurikuler sebagai bentuk kegiatan tambahan kegiatan di sekolah. Dalam kegiatan tersebut harus terlaksana sebaik mungkin tanpa ada perbedaan suku ataupun agama" (wawancara dengan Masyuri Podomi).

Berdasarkan pernyataan di atas dapat dipahami bahwa dengan melalui kegiatan ektrakurikuler ini, para peserta didik serta pembina dalam kegitan tersebut diberi 
kesempatan oleh kepala sekolah untuk mengembangkan talenta mereka sesuai dengan bakatnya masing-masing, sehingga akan mendorong lahirnya wawasan dan kreativitasnya dalam bidang kesenian. Hal ini penting mengingat bahwa pendidikan dalam hal ini adalah kegiatan yang bersifat ekstrakurikuler yang dilaksanakan di sekolah lebih banyak didasarkan pada kurikulum yang telah dipersiapkan, sehingga bentuk, waktu, corak dan hasil-hasil yang diharapkan pada peserta didik sangat terbatas.

Menerapkan kegiatan seni sebagai kegiatan ektrakurikuler salah satu bentuk kegiatan untuk membangun kerjasama antar sesama peserta didik meskipun memiliki karakter dan latar belakang agama, ras, dan suku yang berbeda. Dengan kegiatan seni tersebut para pembina mampu membangun dan memperkenalkan toleransi beragama kepada seuluruh peserta didik sebagai simbol multikultural di Sulawesi Utara.

Kedua, kegiatan pramuka. Kegiatan ekstrakurikuler kepramukaan tentu merupakan kegiatan ektrakurikuler yang bersifat umum. Dalam kegiatan pramuka tersebut tentu menekankan pembelajaran budi pekerti sebagai salah satu ciri khas dalam menjalankan pramuka. Dengan adanya kegiatan pramuka sebagai bagian dari kegiatan ektrakurikuler para pimpinan sekolah dalam hal ini kepala sekolah selalu memberi pesan agar dalam kegiatan kepramukaan tersebut selalu melibatkan peserta didik tanpa harus melihat latar belakang mereka. Artinya, kegiatan kepramukaan ini merupakan salah satu kegiatan yang dilakukan untuk menumbuhkan rasa persaudaraan antara peserta didik yang ada di sekolah ataupun dari luar sekolah. Sebagaimana ungkapan kepala sekolah SMA Negeri 1 Belang yaitu sebagai berikut: "Saya selaku kepala sekolah selalu menekankan kepada pembina kepramukaan kiranya dalam kegiatan ini yang paling utama diterapkan ialah membangun persaudaraan sesama peserta didik yang ada dalam kegiatan tersebut. Artinya, dalam kegiatan pramuka semua sudah dianggap bersaudara dan itu harus sebagaimana motto kita di Sulawesi Utara bahwa "torang samua basudara". Dengan demikian dalam kegitan ini tidak ada lagi perbedaan melainkan semua bersaudara "(wawancara dengan Zulkarnain Tadore). Hal yang sama diungkapkan oleh bapak wakakurikulum SMA Negeri 1 Kotamobagu yang mengatakan bahwa: "Dengan adanya kegiatan pramuka maka tentu tujuan utamanya ialah pembentukan karakter kepada peserta didik menanamkan nilai-nilai budi pekerti. Selain itu, dalam kegiatan kepramukaan ini diharapkan agar ikatan batin antar sesama peserta didik tanpa melihat latar belakang agama, ras atau pun suku. Dengan demikian dalam kegiatan kepramukaan ini tidak hanya pada keilmuan saja melainkan pada implementasi keseharian dalam menerapkan nilai-nilai toleransi umat beragama dalam sekolah maupun di luar sekolah" (wawancara dengan Sanusi Mangkai). Hal yang serupa diungkapkan pula oleh pembina kegiatan ekstrakurikuler pada SMA Negeri 1 Bolangitang yang mengatakan bahwa: "Kepramukaan yang ada di sekolah ini tidak lain ialah bagian dari kegiatan ektrakurikuler yang sangat penting diterapkan di sekolah ini. Pada kegiatan ini salah satu tujuannya ialah agar peserta didik bisa belajar berorganisasi dan saling mengenal lebih dekat tanpa melihat agama dan suku dari masingmasing mahasiswa" (wawancara dengan Intan).

Melihat beberapa pernyataan di atas dapat dipahami bahwa salah satu fungsi dari 
kegiatan pramuka ialah untuk membangun budi pekerti kepada peserta didik dan mampu menerapkan dalam kehidupan sehari-hari. Selain itu, dalam kepramukaan akan mampu menjadi wadah dalam membangun hubungan komunikasi antar peserta didik agar tercipta hubungan yang erat dan saling menghargai antara satu sama lain terutama bagi mereka yang memiliki latar belakang agama dan suku yang berbeda.

Ketiga, kegiatan keagamaan. Kegiatan ekstrakurikuler di bidang keagamaan ini dapat dikatakan tidak kalah pentingnya dengan kegiatan-kegiatan ekstrakurikuler lainnya. Hal ini disebabkan karena bidang keagamaan tertujuan untuk membina dan membentuk kepribadian setiap individu baik dari segi jasmani maupun dari segi rohani.

Kegiatan-kegiatan keagamaan yang dilaksanakan para peserta didik di beberapa SMA Negeri di Sulawesi Utara di antaranya ialah melakukan latihan pidato keagamaan yang didampingi oleh masing-masing guru agama. Latihan pidato keagamaan ini dilakukan agar masing-masing peserta didik mampu mengamalkan ajaran agamanya dalam kehidupan sehari-hari dan mampu tampil di dalam kegaiatan keagamaan yang dilakukan di dalam sekolah maupun di luar sekolah. Hal diungkapkan oleh kepala sekolah SMA Negeri 1 Kotamobagu yang mengatakan bahwa: "Dalam kegiatan ektrakurikuler di SMA Negeri 1 Kotamobagu kami selaku kepala sekolah tentu menginginkan agar para peserta didik selalu taat beribadah kepada Tuhan Yang Maha Esa. Selain itu, salah satu kegiatan keagamaan ini agar peserta didik yang ada di SMA Negeri Kotamobagu ini mampu tampil di tengah-tengah masyarakat minimal melakukan khotbah atau ceramah keagamaan. Dengan demikian, saya selaku pimpinan pada sekolah ini akan selalu memberi semangat dan motivasi kepada para peserta didik dan para pembina dalam kegiatan keagamaan di sekolah ini" (wawancara dengan Masyuri Podomi). Hal yang sama diungkapkan pula oleh Sanusi mamangkei wakil kepala sekolah SMA Negeri 1 Kotamobagu yang menmbahkan bahwa: "Salah satu fungsi dilakukannya kegiatan keagamaan ini ialah untuk menyelesaikan pembelajaran yang tidak tuntas pada pembelajaran agama di kelas. Selain itu, kegiatan ektrakurikuler ini bertujuan untuk mewujudkan berbagai pembelajaran yang sifatnya memerlukan waktu yang cukup lama seperti tadzkir bagi peserta didik yang beragama Islam. Tidak hanya itu, dalam kegiatan ini para pembina juga selalu melakukan pelatihan kegiatan keagamaan yang di mana kegiatan ini akan ditampilkan saat kegiatan hari-hari besar keagamaan" (wawancara dengan Sanusi Mangkai).

Melihat kegiatan di atas dapat dipahami bahwa kegitan ekstrakurikuler di bidang keagamaan yang dilaksanakan di beberapa SMA Negeri di Sulawesi Utara bertujuan untuk selalu meningkatkan keilmuan bagi para peserta didik. Keilmuan yang dimaksudkan di sini bukan hanya ilmu keorganisasian melainkan juga ilmu keagamaan yang akan menjadi bekal bagi para peserta didik ketika terjun dimasyarakat. Selain itu, bekal dan keilmuannya mampu menjadi masyarakat yang majemuk berbasis multikultural karena dalam kegiatan ekstrakurikuler yang selalu dilaksanakan di sekolah sudah melekat dalam diri para peserta didik. Dengan demikian sikap toleransi antara satu peserta didik dengan peserta didik lainnya menyatu dalam hati masing-masing individu peserta didik. 
Kegiatan-kegiatan ekstrakurikuler yang dilaksanakan oleh para peserta didik di SMA Negeri yang ada di Sulawesi Utara bertujuan agar dapat terarah dan memberi manfaat terhadap peningkatan bakat dan kreativitas peserta didik. Peranan dan keterlibatan para pembina, dalam hal ini adalah para guru yang ada sekolah masingmasing memiliki arti yang sangat penting, sehingga kegiatan yang dilakukan peserta didik pada masing-masing sekolah tersebut memberikan manfaat terhadap kegiatankegiatan ekstrakurikuler.

Sebagai bagian dari kegiatan-kegiatan pendidikan yang tercakup dalam kegiatan kurikuler, kegiatan ekstrakurikuler semaksimal mungkin tidak mengganggu kegiatan intrakurikuler, meskipun hal ini juga merupakan penunjang kegiatan intrakurikuler dan dilaksanakan di luar jam pelajaran. Kegitan ekstrakurikuler keagamaan yang dilaksanakan dalam setiap lembaga pendidikan (sekolah) meskipun bukan bagian mutlak yang harus dilaksanakan setiap sekolah, di mana setiap kegiatan ekstrakurikuler tersebut tidak diberi nilai sebagaimana kegitan-kegiatan kurikuler lainnya. Namun sangat menunjang bagi peningkatan bakat dan kreativitas para peserta didik melalui berbagai kegiatan di pilih sendiri oleh peserta didik terutama dalam membangun keakraban antara peserta didik dalam mewujudkan nilai-nilai multikultural.

Ditinjau dari partisipasi para peserta didik di SMA Negeri yang ada di Sulawesi Utara terhadap kegiatan ekstrakurikuler yang dilaksanakan oleh para pembina yang sangat positif, melambangkan bahwa kepribadian para peserta didik, telah transparan dengan nilai-nilai religi dan menyadari akan pentingnya kegiatan ekstrakurikuler dalam rangka meningkatkan nilai-nilai multikultural bagi para peserta didik menuju kepada ketahanan mental meraka secara tidak langsung, yang pada gilirannya dapat mengantarkan kepada kelancaran proses dan hasil belajar yang maksimal.

Mencermati keterangan dari beberapa informan, maka penulis dapat memberikan suatu analisis bahwa ciri khas para pembina pada kegiatan ektrakurikuler di SMA Negeri se-Sulawesi Utara jika tinjau dari kepribadiannya dirasakan cukup tinggi dan menunjukkan sikap tanggung jawab dalam melaksanakan tugasnya sebagai pembina sekaligus sebagai pengajar serta sangat mencintai kegiatan-kegiatan yang bersifat ekstrakurikuler dalam hal ini juga terkait dengan kegiatan ekstrakurikuler tanpa mendeskripsikan agama atau keyakinan terhadap peserta didik itu sendiri.

Dapat pula dipahami bahwa selain faktor pembina sebagai alasan keikutsertaan peserta didik dalam kegiatan ektrakurikuler juga telah dipengaruhi pula oleh tanggungjawab sebagai peserta didik yang ada di masing-masing sekolah yang ada di SMA Negeri se-Sulawesi Utara. Artinya, kegiatankegiatan ekstrakurikuler diminati peserta didik karena lebih menambah wawasan dan bisa menjadi referensi atau sumber pengetahuan bagi peserta didik dalam mengembangkan bakatnya serta sebagai pengetahuan khusus dalam memahami karakter yang ada di sekeliling mereka.

Yang bersifat material dapat berupa benda-benda yang merupakan suatu hasil karya, seperti benda-benda seni rupa, mobile, peralatan kerja, perlengkapan rumah tangga, dan sebagainya. Sedangkan, yang bersifat non-material dapat berupa pengetahuan, keterampilan, seni budaya seperti tari, puisi, sajak dan lain sebagainya. Dari keseluruhan hal tersebut dapat menunjukkan suatu hasil 


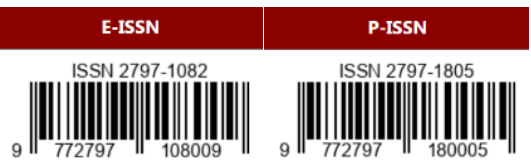

keberhasilan suatu upaya yang dilakukan untuk menghasilkan sesuatu sekaligus sebagai tolak ukur sejauh mana efektivitas dari suatu kegiatan tersebut.

Dengan demikian hasil-hasil yang dicapai oleh suatu kegiatan tersebut merupakan pencapaian keberhasilan usaha yang dilakukan. Jadi, dapat diartikan sebagai "sesuatu yang dapat memberikan petunjuk atau keterangan". Petunjuk atau keterangan yang dimaksudkan dalam pembahasan ini adalah sekitar keberhasilan atau hasil-hasil yang telah dicapai peserta didik di SMA Negeri se-Sulawesi Utara sebagai bukti adanya kegiatan ekstrakurikuler dalam membentuk akhlak mulia peserta didik terutama dalam membangun sikap toleransi umat beragama dari masing-masing sekolah.

Sebagaimana yang telah dikemukakan mengenai bentuk-bentuk kegiatan ekstrakurikuler keagamaan di SMA Negeri se-Sulawesi Utara yaitu mencakup kegiatan di bidang kesenian, dan kegiatan-kegiatan di bidang keagamaan lainnya, maka untuk mengetahui tingkat keberhasilan kegiatan ekstrakurikuler dapat dilihat dalam kehidupan sehari-hari terutama pada sikap terhadap teman-teman mereka.

\section{Pelaksanaan}

program-program kegiatan ekstrakurikuler hendaknya dikendalikan untuk pencapaian tujuan-tujuan yang telah diterapkan dan kontribusinya terhadap perwujudan visi sekolah. Dari setiap pelaksanaan program kegiatan ekstrakurikuler hendaknya diusahakan suasana yang kondusif, tidak terlalu membebani siswa dan tidak merugikan aktivitas kurikuler sekolah. Usahakan pelaksanaan kegiatan konsisten sebagaimana terjadwal dan terpublikasikan. Kerja sama tim adalah fundamental, hindari pembatasan untuk partisipasi. Setiap personil disekolah, sesuai dengan fungsinya, pada dasarnya bertanggungjawab atas pengembangan program ekstrakurikuler yang diselenggarakan.

Adapun ragam dan banyaknya sumber daya manusia yang diperlukan untuk menangani pengelolaan program ekstrakurikuler itu tergantung pada kebutuhan yang berkembang, kompleksitas tugas-tugas penyelenggaraan program, dan kebijakan dari pimpinan sekolah sebagaimana hasil kesepakatan antar pihak yang berkepentingan (stakeholders).

Selanjutnya, dalam pengelolaan kegiatan ekstrakurikuler di SMA Negeri seSulawesi Utara dapat dilakukan dengan beberapa tahapan di antaranya ialah:

Pertama, melakukan perencanaan kegiatan ekstrakurikuler. Dalam melakukan perencanaan pada kegiatan ekstrakurikuler dapat dilihat sebagai berikut: (1) menentukan dan menyusun kegiatan ekstrakurikuler, yang meliputi menentukan program kegiatan ekstrakurikuler bidang seni yang sesuai dengan madrasah, kemudian memilih peserta didik yang memiliki potensi dibidang seni tersebut dari hasil seleksi yang saya lakukan, selanjutnya mengatur jadwal latihan; (2) penyusunan tentang jadwal latihan kegiatan ekstrakurikuler untuk peserta didik, yang meiliputi menyusun waktunya latihan, jadwal latihannya saya susun dalam seminggu satu kali pertemuan; (3) penyusunan tata tertib dalam mengikuti kegiatan ekstrakurikuler yang meliputi, membuat daftar kehadiran peserta didik dalam latihan kegiatan kestrakurikuler bidang seni. Bagi yang jarang hadir/tidak serius dalam mengikuti kegiatan ekstrakurikuler bidang seni maka akan diberi sanksi hingga namanya akan dicoret.

Kedua, pelaksanaan kegiatan ekstrakurikuler. Pelaksanaan programprogram kegiatan ekstrakurikuler hendaknya 
dikendalikan untuk pencapaian tujuan-tujuan yang telah diterapkan dan kontribusinya terhadap perwujudan visi sekolah. Dari setiap pelaksanaan program kegiatan ekstrakurikuler hendaknya diusahakan suasana yang kondusif, tidak terlalu membebani siswa dan tidak merugikan aktivitas kurikuler sekolah. Usahakan pelaksanaan kegiatan konsisten sebagaimana terjadwal dan terpublikasikan.

Selanjutnya, kerja sama tim dalam kegiatan ektrakurikuler merupakan fundamental, hindari pembatasan untuk partisipasi. Setiap personil disekolah, sesuai dengan fungsinya, pada dasarnya bertanggung jawab atas pengembangan program ekstrakurikuler yang diselenggarakan. Adapun ragam dan banyaknya sumber daya manusia yang diperlukan untuk menangani pengelolaan program ekstrakurikuler itu tergantung pada kebutuhan yang berkembang, kompleksitas tugas-tugas penyelenggaraan program, dan kebijakan dari pimpinan sekolah sebagaimana hasil kesepakatan antar pihak yang berkepentingan (stakeholders). Intinya dari kegiatan ektrakurikuler ialah peserta didik mampu berorganisasi dan mampu memaknai perbedaan antara satu sama lain.

Ketiga, melakukan pengontrolan pada kegiatan ekstrakurikuler. Melakukan pengontrolan pada kegiatan ektrakurikuler merupakan kegiatan yang sangat penting dilakukan oleh pimpinan. Pimpinan yang dimaksudkan di sini ialah para kepala sekolah yang ada pada masing-masing sekolah. Salah satu upaya dilakukannya pengontrolan pada kegiatan ini yaitu untuk memastikan apakah apa yang telah direncanakan sebelumnya berjalan sebagaimana mestinya atau tidak. Jika tidak berjalan sebagaimana mestinya maka dilakukan proses untuk mengoreksi kegiatan yang sedang berjalan agar tetap mencapai apa yang elah direncanakan. Dalam kegiatan ektrakurikuler di SMA Negeri seSulawesi Utara diperlukan pengontrolan guna untuk memahami tingkat kesulitan dalam kegiatan ekstrakurikuler tersebut. Selain itu, dalam melakukan pengawasan pimpinan dalam hal ini kepala sekolah harus mampu mengotrol segala kegiatan ektrakurikuler agar dapat terlaksana semaksimal mungkin dengan tujuan sebagaimana yang telah direncanakan.

Dalam wawancara pada hasil penelitian telah diungkapkan oleh beberapa kepala sekolah bahwa usaha yang dilakukan untuk melakukan kontrolling pada kegiatan ektrakurikuler ialah untuk menekankan kepada seluruh pembina dalam kegiatan ekstrakurikuler agar tetap menerapkan dan tetap selalu menyampaikan kepada pserta didik agar selalu menjaga kerukunan umat beragama sebagai lambang atau motto wilayah Sulawesi Utara sebagai masyarakat yang majemuk dengan mengedepankan persaudaraan.

Evaluasi program kegiatan ekstrakurikuler di maksudkan untuk mengumpulkan data atau informasi mengenai tingkat keberhasilan yang dicapai siswa. Penilaian dapat dilakukan sewaktu-waktu untuk menetapkan tingkat keberhasilan siswa pada tahap-tahap tertentu dan untuk jangka waktu tertentu berkenan dengan proses dan hasil kegiatan ekstrakurikuler. Penilaian program ekstrakurikuler menekankan pada penilaian/tes tindakan yang dapat mengungkapkan tingkat untuk perilaku belajar/kerja siswa.

Penetapan tingkat keberhasilan untuk program ekstrakurikuler didasarkan atau standar minimal tingkat penguasaan kemampuan yang disyaratkan dan bersifat individual. Penilaian secara inklusif mempertimbangkan pembentukan kepribadian yang terintegrasi jiwa 
kemandirian atau kewirausahaan sikap dan etos perilaku itumempertimbangkan kemahiran dalam pemecahan masalah dan berkomunikasi. Mempertimbangkan standart keadilan dan keragaman secara individual bagi setiap siswa, dan mempertimbangkan tingkat partisipasi aktif dalam kegiatan ekstrakkurikuler yang dilakukan. Penilaian dilakukan dengan memandang bobot yang sama baik terdapat proses dan hasil akhir dari setiap kegiatan ekstrakurikuler yang dilakukan.

Penilaian melalui pemberian tugas secara bervariasi mendorong tumbuhnya rasa tanggung jawab yang tinggi. Ujian kemampuan atau tingkat kemahiran yang telah dicapai siswa dan sertifikasi dilakukan secara bersama sehingga dapat dipercaya dan dipertanggungjawabkan.

Selanjutnya, dalam melakukan evaluasi yang paling utama dilakukan selain kegiatan ektrakurikuler ialah memeriksan seluruh laporan keuangan. Artinya, pembina hendaknya membuat laporan, baik laporan untuk keseluruhan program kegiatan ekstrakurikuler dan untuk setiap jenis kegiatan ekstrakurikuler ataupun untuk pertanggungjawaban keuangan yang telah dialokasikan/digunakan untuk kegiatan yang dimaksudkan.

Untuk laporan kegiatan, hendaknya dibuat format yang sederhana tetapi cukup komprehensif dan mudah dipahami, misalnya mencakup: kata pengantar, hasil yang diharapkan, organisasi penyelenggaraan, jadwal dan mekanisme pelaksanaan, bentuk penghargaan, hasil yang diperolah, kesulitan yang dijumpai dan usaha mengatasi kesulitan itu, kesimpulan keseluruhan dan saran-saran yang diajukan, serta lampiran-lampiran yang diperlukan.

\section{KESIMPULAN DAN SARAN}

\section{Kesimpulan}

Kesimpulan dalam penelitian ini adalah sebagai berikut.

1. Pembelajaran ektrakurikuler bernuansa multikultural di SMA Negeri se-Sulawesi Utara telah dilaksanakan semaksimal mungkin. Artinya, kegiatan ektrakurikuler tersebut telah diprogramkan oleh seluruh sekolah SMA Negeri se-Sulawesi Utara meskipun kegiatan tersebut dilaksanakan di luar jam pelajaran. Adapun bentukbentuk kegiatan umum dalam kegitan ektrakurikuler di SMA Negeri seSulawesi Utara yaitu latihan pidato, kegiatan pramuka dan kegiatan keagamaan yang dibinah langsung oleh guru agama masing-masing.

2. Pengelolaan pembelajaran bernuansa multikultural pada kegiatan ekstrakurikuler di SMA Negeri seSulawesi Utara yaitu melakukan perencanaan terkait kebutuhan dan fasilitas kegiatan yang akan dilakukan dalam kegiatan ekstrakurikuler. Perencanaan yang dimaksudkan di sini yaitu para pembina harus membuat program kegiatan di akhir tahun dan akan mulai dilaksanakan pada awal tahun berikutnya. Kemudian setelah kegiatan terlaksana pimpinan melakukan pengawasan sebagai bentuk pengontrolan dari pimpinan yang bertujuan untuk mengetahui sejauhmana capaian yang dicapai dalam kegiatan ekstrakurikuler. Inti dari pengawasan ini ialah kepala sekolah melakukan pengawasan sekaligus penyampaian bahwa dalam kegiatan ekstrakurikuler ini diharapkan seluruh peserta kegiatan ektrakurikuler mampu memujudkan kebersamaan dan membentuk keakraban serta persaudaraan 
tanpa melihat latar belakang status agama, suku ataupun ras dari masing-masing peserta didik. Selanjutnya, melakukan evaluasi yang bertujuan untuk mengetahuai hasil dari keseluruhan kegiatan terutama pada laporan kegiatan dan keuangan dari kegiatan ektsrakurikuler.

\section{Saran}

Dengan memperhatikan kesimpulan di atas, maka beberapa saran yang dikemukakan antara lain: Pertama, kepada pembina dan pengelola kegiatan ekstrakurikuler, agar terus mempertahankan dan meningkatkan kerja sama seluruh pihak yang terlibat dalam kegiatan ekstrakurikuler di sekolah dalam menunjang kesuksesan ekstrakurikuler dalam mencapai tujuan yang diinginkan. Kedua, kepada pembina dan guru yang terlibat dalam pelaksanaan kegiatan ekstrakurikuler, agar memberikan pembinaan bagi peserta didik dalam mengembangkan kompetensi peserta didik dengan baik terutama dalam menjaga toleransi umat beragama pada kehidupan sehari-hari.

\section{DAFTAR PUSTAKA}

Arikunto, S. (1998). Manajemen Penelitian. Rineka Cipta.

Ardianto, A., Gonibala, R., Hadirman, H., \& Lundeto, A. (2020). NILAI PENDIDIKAN KARAKTER

BANGSA DALAM TRADISI KATOBA PADA MASYARAKAT ETNIS MUNA. Potret Pemikiran, 24(2), 86-107

Baroroh, Hanik. "Manajemen Pendidikan Nilai-Nilai Multikultural Dalam Pembentukan Karakter Religius Siswa Di Man Yogyakarta Iii Tahun Pelajaran."
Bolotio, R., Hadirman, H., \& Musafar, M. (2021). Prolematika Pengelolaan Pendidikan Islam Non-Formal Pada Komunitas Muslim. Jurnal Ilmiah Iqra', 15(1), 32-47.

Daradjat, Z. (2006). Ilmu Pendidikan Islam. Bumi Aksara.

Departemen Pendidikan dan Kebudayaan R.I,

D. D. (1994). Bahan Dasar Peningkatan Wawasan Kependidikan Pendidik Agama. Darma Gemilang.

Luma, M., Tola, A., \& Hadirman, H. (2020). Evaluasi Implementasi K-13 Berdasarkan Model CIPP di SDN 2 Tabongo Kabupaten Gorontalo. Jurnal Ilmiah Iqra', 14(2), 186-204.

Lexy Moleong. (2017). Metode Penelitian Kualitatif. PT. Remaja Rosdakarya.

Makawimbang, J. H. (2011). Supervisi dan Peningkatan Mutu Pendidikan. Alfabeta.

Makmun, A. S. (2015). Psikologi Kependidikan. PT Remaja Rosda Karya.

Muhaimin. (2010). Paradigma Pendidikan Islam. Remaja Rosda Karya.

Muliono. (2008). Manajemen Administrasi dan Organisasi Pendidikan. Ar-Ruzz Media.

Mulyana, R. (2013). Mengartikulasikan Pendidikan Nilai. Alfabeta.

Musbikin, I. (2013). Menjadi Kepala Sekolah Yang Yang Hebat. Zanafa Publishing.

Nata, A. (2010). Paradigma Pendidikan Islam. Grasindo.

Ni'mah, Zur'atun. Pembelajaran Pendidikan Agama Bernuansa Multikultural Dalam Membangun Budaya Toleransi Beragama Siswa (Studi Multi Kasus Dua SMP di Kota Malang). Diss. 
University of Muhammadiyah Malang, 2012.

Primawati, Laurencia. "Pembelajaran

Multikultural melalui Pendidikan

Multikultural Berbasis Nilai

Kebangsaan." JUPIIS: JURNAL

PENDIDIKAN ILMU-ILMU

SOSIAL 5.2 (2014).

Sanafiah Faisal. (2001). Metodologi Penelitian Sosial. Erlangga.

Satori, D. (2009). Metode Penelitian Kualitatif. Alfabeta.

Sehartian, P. A. (1985). Prinsip dan Teknik Supervisi Pendidikan. Usaha Nasional.

Sudjana, N. (2010). Penilaian Hasil Proses Belajar Mengajar. Rosda Karya.

Sugiono. (2010). Metode Penelitian Pendidikan Pendekatan Kualitatif, Kuantitatif, dan $R \& D$. Alfabeta.

Suryosubroto, B. (2009). Proses Belajar Mengajar Di Sekolah. Rineka Cipta.

Suwarno. (2001). Pengantar Ilmu Pendidikan. Angkasa.

Usman, M. U. (2000). Menjadi Pendidik Profesional. Rosdakarya. 